\title{
ОБЩЕСТВЕННЫЙ КОНТРОЛЬ ЗА ОБЕСПЕЧЕНИЕМ ПРАВ ЛИЦ, СОДЕРЖАЩИХСЯ В МЕСТАХ ЛИШЕНИЯ СВОБОДЫ: ЗАКОНОДАТЕЛЬСТВО И ПРАКТИКА РЕАЛИЗАЦИИ
}

\begin{abstract}
АНнОТАЦИЯ. В статье представлен анализ законодательства, регулирующего общественный контроль за обеспечением прав человека в местах принудительного содержания. На основании результатов проведенного анализа посещений мест принудительного содержания, изучения статистики обращений и жалоб осужденных, содержащихся в исправительных учреждениях можно констатировать, что недостатки касаются вопросов: материально-бытового и медико-санитарного обеспечения осужденных, обеспечения режимных требований, порядка направления обращений осужденных, ведения ими переписки и др. Практика осуществления контроля общественной наблюдательной комиссии в субъекте РФ (Новосибирская область) показывает, что своевременное реагирование комиссии на выявленные нарушения уголовно-исполнительного законодательства обеспечивает соблюдение законности и подчеркивает значимость деятельности комиссии в процессе соблюдения прав человека в местах принудительного содержания. Рассматривая опыт организации и осуществления общественного контроля, автор обосновывает необходимость внесения изменений и дополнений в статьи Федерального закона № 76-ФЗ в целях совершенствования и имеющих значение в практике реализации общественного контроля уголовно-исполнительной системы.

кЛючЕВЫЕ СЛОВА. Общественный контроль; осужденные; общественная наблюдательная комиссия; пенитенциарные учреждения; уголовно-исполнительное законодательство.

ИНФОРМАЦИЯ О СТАТЬЕ. Дата поступления 14 октября 2016 г.; дата принятия к печати 2 ноября 2016 г.; дата онлайн-размещения 30 ноября 2016 г.
\end{abstract}

M. V. Minster

National Research Tomsk State University, Novosibirsk, Russian Federation

\section{PUBLIC CONTROL OF PROVIDING RIGHTS OF PERSONS KEPT IN PLACES OF DETENTION: LEGISLATION AND IMPLEMENTATION PRACTICE}

\begin{abstract}
The article presents an analysis of the legislation regulating public control of providing rights of persons in places of detention. Using the results of an analysis made after visiting places of detention, studying statistics of petitions and complains of the convicts kept in penitentiary facilities, the article notes that problems are dealt with convicts' living and healthcare conditions, provision of secure requirements, order of directing convicts' petitions, their carrying correspondence, and others. The practice of control implementation by the public supervising committee in a territorial entity of the RF (Novosibirsk Oblast) shows that the timely response of the committee to the identified breaches of the correctional law provides the due process of law and underlines the significance of the committee's activity in the process of human rights observance in places of detention. Considering the organization's experience and provision of public control, the author substantiates the need of introducing changes and amendments to the articles of the Federal Law № 76-Ф3 in order to master the correctional system, that are significant in the practice of implementing public control.
\end{abstract}

(C) M. В. Минстер, 2016

\section{Baikal Research Journal}


KEYWORDS. Public control; convicts; public supervising committee; penitentiary facilities; correctional law.

ARTICLE INFO. Received October 14, 2016; accepted November 2, 2016; available online November 30, 2016.

Основная задача гражданского общества состоит в обеспечении условий для наиболее полного удовлетворения многообразных интересов и потребностей членов общества в процессе их свободной самодеятельности и самоорганизации. Государство и гражданское общество неразрывно связаны друг с другом, составляют две части единого социального организма. Для развития гражданского общества требуется постоянный и взаимозаинтересованный диалог государства и общества [1, с. 4].

Проблема взаимодействия гражданского общества с государством многоаспектна, но особую остроту она приобретает в тех случаях, когда речь идет о реализации государственного принуждения по отношению к членам общества. Многочисленные факты необоснованного, неадекватного применения государственного принуждения в деятельности различных государственных структур - пока далеко не исключение, и поэтому каждое такое событие, получившее общественный резонанс, вызывает в обществе вполне объяснимую реакцию в виде попыток в тех или иных формах контролировать действия государственных органов, оказывать влияние на них. Однако далеко не всегда эти попытки обоснованы и носят конструктивный характер. Это в полной мере можно отнести и к проблеме контроля обществом за деятельностью такого элемента государственного механизма, как уголовно-исполнительная система [2, с. 3].

В изменяющихся политических и социально-экономических условиях важно обеспечить законность исполнения уголовных наказаний, соблюдение законных прав и интересов лиц, содержащихся в местах лишения свободы. Обеспечение правового статуса этих лиц, в том числе путем осуществления общественного контроля, признано приоритетной задачей в ряде международных соглашений [3, с. 57]. Для осуществления общественного контроля необходимо как минимум два условия: наличие развитого гражданского общества, а также такие условия взаимодействия государства и гражданского общества, в которых они представлены как равноправные субъекты [4, с. 34].

Важное место в механизме реализации уголовно-исполнительной политики занимает обеспечение гласности в деятельности уголовно-исполнительной системы, ее подконтрольности институтам гражданского общества, создание условий для участия общественности в решении стоящих перед уголовно-исполнительной системой задач. Это требует основательного научного анализа сущности и содержания контрольной деятельности общественных формирований [5, с. 4 ].

Проблема соблюдения прав человека в сфере уголовно-исполнительной системы (УИС) России в настоящие время приобретает все большую актуальность и заинтересованность среди ученых и практиков в связи с недостаточно эффективной реализацией прав и свобод лиц, находящихся в местах лишения свободы. Актуальным вопросам общественного контроля посвящено немало научных работ по социологии [6-8], юриспруденции [9, с. 35] и др. В связи с этим возникает необходимость исследования данной проблематики с учетом анализа законодательства, результатов его практического применения, оценки эффективности, а также определения дальнейших перспектив развития общественного контроля за деятельностью уголовно-исполнительной системы.

Социальное назначение общественного контроля за обеспечением прав осужденных в местах лишения свободы заключается, прежде всего, в сохранении жизни, здоровья, человеческого достоинства и обеспечении нормального суще-

\section{Baikal Research Journal}

электронный научный журнал Байкальского государственного университета 
ствования осужденных в местах лишения свободы; обеспечении оптимального функционирования исправительных учреждений; создании материальных условий как основы для исправления осужденных, их ресоциализации. Специфика общественного контроля в рассматриваемой области такова, что от степени ее эффективности во многом зависят как судьбы осужденных, их жизнь, физическое и нравственное здоровье, так и состояние безопасности общества в целом [3, с. 58]. Так, отбывание наказания в виде лишения свободы связано с рядом негативных факторов, которые затрудняют социальную адаптацию лиц, освобожденных из исправительных учреждений. Усвоение элементов криминальной субкультуры, ослабление семейных и родственных связей, неумение принимать позитивные решения в различных жизненных ситуациях, настороженное отношение со стороны окружающих на свободе создают освободившимся осужденным значительные трудности, особенно в течение первых месяцев свободной жизни [10, с. 48]. Своевременное корректирование со стороны общественности исправительного воздействия на осужденных позволяет не только увеличить шансы на возвращение в общество законопослушного человека, но и предупредить рецидив преступлений.

Федеральный закон «Об общественном контроле за обеспечением прав человека в местах принудительного содержания и содействия лицам, находящимся в местах принудительного содержания» от 10 июня 2008 г. № 76-ФЗ ${ }^{1}$ (далее - ФЗ № 76-Ф3) был принят во исполнении ст. 23 Уголовно-исполнительный кодекс РФ «Содействие общественных объединений в работе учреждений и органов, исполняющих наказания» ${ }^{2}$. В соответствии с которой общественные объединения оказывают содействие в работе органов и учреждений, исполняющих наказания, принимают участие в исправлении осужденных. На основании и в порядке предусмотренном действующим законодательством Российской Федерации, общественный контроль за обеспечением прав человека осуществляют общественные наблюдательные комиссии, образованные в субъектах РФ. Так, в соответствии со ст. 5 Ф3 № 76-ФЗ общественный контроль осуществляют: общественные наблюдательные комиссии (ОНК), образуемые в субъектах Российской Федерации, которые относятся к институтам гражданского общества, уполномоченным на осуществления общественного контроля в данной сфере и наделяет ОНК и их членов контрольными полномочиями и предусматривает конкретные формы содействия.

Таким образом, основным направлением контрольной деятельности общественных структур в пенитенциарной сфере является проверка соблюдения прав, свобод и законных интересов осужденных. Для этого используются разнообразные формы: посещение исправительных учреждений, рассмотрение предложений, заявлений и жалоб, подготовка решений по результатам проведения контроля, т. д.

Общественные организации правозащитной направленности, одними из которых являются ОНК, уделяют особое внимание деятельности УИС, так как наряду с многочисленными примерами высокого профессионализма при выполнении должностных обязанностей сотрудниками исправительных учреждений встречаются случаи нарушения прав и свобод осужденных и подследственных.

ОНК являясь органами общественного контроля, не наделены властными полномочиями и реализуют результаты контрольной деятельности опосредованно через соответствующие государственные органы. Подготовленные документы в

${ }^{1}$ Об общественном контроле за обеспечением прав человека в местах принудительного содержания и содействия лицам, находящимся в местах принудительного содержания : федер. закон РФ от 10 июня 2008 г. № 76-ФЗ // Собрание законодательства. 2008. № 24. Ст. 2789.

${ }^{2}$ Уголовно-исполнительный кодекс Российской Федерации : федер. закон от 8 янв. 1997 г. № 1-ФЗ (ред. от 28 нояб. 2015 г., с изм. и доп., вступ. в силу с 1 янв. 2016 г.). //Там же. 1997. № 2. Ст. 198.

\section{Baikal Research Journal}

электронный научный журнал Байкальского государственного университета 
форме (заключений, предложений и т. п.) для принятия мер носят рекомендательный характер и направляются в уполномоченные государственные органы. На практике такие рекомендации чаще всего не учитываются. Проблема состоит в том, что органы и организации, в отношении которых производится контроль, не несут ответственности за неучет рекомендаций контролеров и даже не обязаны публично объяснять причины отказа [11, с. 1398].

Успешная работа ОНК возможна лишь при соблюдении гарантий их независимости и беспристрастности, поэтому Общественная палата РФ продолжает оказывать помощь региональным ОНК в их становлении как методического, так и организационно-технического характера. Одним из ключевых условий эффективной деятельности ОНК является - расширение объема информации и адекватное ее использование, особенно касающейся защиты прав и законных интересов осужденных и лиц, подозреваемых в совершении преступлений, находящихся в местах принудительного содержания.

2 августа 2014 г. вступил в силу Федеральный закон Российской Федерации «Об основах общественного контроля в Российской Федерации» от 21 июля 2014 г. № 212-Ф3, который устанавливает правовые основы организации и осуществления общественного контроля за деятельностью полиции, органов следствия, прокуратуры, судов, за деятельностью, связанной с исполнением наказаний. Целями общественного контроля являются - не только обеспечение реализации и защиты прав и свобод человека и гражданина, но и прав и законных интересов общественных объединений и иных негосударственных некоммерческих организаций ${ }^{3}$. В рамках этого закона общественные наблюдательные комиссии являются субъектами общественного контроля.

В настоящее время в России сложилась определенная практика общественного контроля в пенитенциарной сфере. Применение законодательства в процессе осуществления контроля членами ОНК по Новосибирской области свидетельствует о следующем положении дел. Так, например, за 2015 г. комиссия осуществила 67 посещений мест принудительного содержания. Кроме того, членами ОНК проведено 342 личных приема граждан, родственников, осужденных и лиц, находящихся под следствием, получено и рассмотрено 112 письменных жалоб и обращений и 74 обращения, поступившие на электронные адреса ОНК. По результатам проверок подготовлено и отправлено в различные инстанции 83 заключения.

Выявленные нарушения уголовно-исполнительного законодательства в исправительных учреждениях касались: материально-бытового обеспечения осужденных - 43, медико-санитарного обеспечения осужденных - 109, обеспечения режимных требований -23 , порядка направления обращений осужденных, ведения ими переписки -11.

В исправительных учреждениях Новосибирской области отбывают наказание около 17500 осужденных. Контроль осуществляется, как членами комиссии самостоятельно, так и совместно с сотрудниками Главного управления Федеральной службы исполнения наказаний (ГУФСИН), Прокуратуры, Уполномоченным по правам человека по Новосибирской области. Количество поступивших жалоб составило 1,06 \% от общего количества осужденных и практически по всем поступившим жалобам проверки проводились с выездом в исправительные учреждения. В процессе проверок проводились беседы с руководством исправительных учреждений, опросы осужденных, в некоторых случаях изучались личные дела осужденных и иные документы. По жалобам на неудовлетворительное медицин-

${ }^{3}$ Об основах общественного контроля в Российской Федерации : федер. закон от 21 июля 2014 г. № 212-ФЗ // Российской газета. 2014. 23 июля.

\section{Baikal Research Journal}

электронный научный журнал Байкальского государственного университета 
ское обеспечение или несвоевременное оказание медицинской помощи осужденным проверки проводились с привлечением специалистов.

$\mathrm{C}$ целью снижения количества жалоб и обращений, поступающих от осужденных членами ОНК проводится разъяснительная работа с осужденными по месту отбывания ими наказания. Так, в процессе проведения лекций, бесед в группах осужденных и индивидуально с осужденным разъясняются вопросы:

- о порядке обращения с жалобами в органы власти и иные организации, компетенция указанных органов;

- о полномочиях руководителей исправительных учреждений по разрешению обращений и оперативность их разрешения;

- уголовно-исполнительного и иного законодательства с учетом актуальности вопросов, поставленных в обращениях.

Совместно с прокуратурой и ГУФСИН, ОНК может разрешать сложные и проблемные ситуации, возникающие в исправительных учреждениях. Однако на решение вопросов, связанных с отсутствием финансирования: ремонтных работ, в том числе на проведение капитального ремонта в помещениях; на оснащение новым оборудованием медсанчастей учреждений, к сожалению ОНК повлиять не может.

Результаты проведенного анализа посещений мест принудительного содержания, обращений и жалоб осужденных, подозреваемых и обвиняемых, показали следующее положение. Приведем несколько примеров. Так, в процессе посещения женской исправительной колонии выявлено, что в медицинской части нет постоянного гинеколога (вакансия) и прием осужденных женщин осуществляется только два раза в неделю приходящим гинекологом, кроме того, используется для обследования устаревший аппарат ультразвуковых исследований. Далее, в процессе плановой проверки изолятора временного содержания и дежурной части выявлены недостатки: канализация находится в плохом состоянии и требует капитального ремонта; отсутствуют полотенца и т. д.

Осужденные в жалобах и обращениях указывают на то что, после общения с членами ОНК к ним часто проявляется предвзятое отношение со стороны администрации учреждений. Кроме того, в ОНК продолжают поступают жалобы от осужденных на: тяжелые бытовые условия, особенно в исправительных учреждениях, где отбывают наказание осужденные женщины; отсутствие в исправительной колонии в достаточном количестве комнат для длительных свиданий, в связи с чем невозможно реализовать право на свидание; отсутствие информации для работающих осужденные о начислении зарплаты, а также куда и в каком объеме производятся вычеты; незаконное водворение в штрафной изолятор (ШИЗО), помещения камерного типа (ПКТ, ЕПКТ); ассортимент и необоснованно завышенные цены товаров, продуктов питания. Имеют место жалобы на грубое отношение к подозреваемым, обвиняемым и осужденным во время проведения обысков помещений, личного досмотра и досмотра вещей. Безусловно, перечисленные выше факты прямо или косвенно влияют на процесс адаптации человека на свободе.

По итогам неоднократных проверок соответствия технического состояния лечебных помещений и соблюдения норм жилой площади осужденных, содержащихся в терапевтическом отделении лечебно-исправительного учреждения (ЛИУ), членами ОНК подготовлено обращение в прокуратуру Новосибирской области в связи с необходимостью строительства нового корпуса больницы. В результате на внеочередном заседании Экспертного совета при Уполномоченном по правам человека Новосибирской области, принято решение о направлении в Федеральной службе исполнения наказаний (ФСИН) России рекомендаций о проектировании и строительстве терапевтического корпуса ЛИУ ГУФСИН России по Новосибирской области.

\section{Baikal Research Journal}


Основным методом работы членов наблюдательных комиссий было избрано не только осуществление контроля, но и сочетание его с оказанием содействия лицам, находящимся в местах принудительного содержания. При этом многих членов ОНК отличал серьезный, вдумчивый подход к осуществлению общественного контроля в комплексе со стремлением оказать помощь лицам, находящимся в местах лишения свободы в решении их насущных жизненных проблем.

Необходимо отметить, что ОНК по Новосибирской области выступает инициатором и участвует в проведении различных акций, например, по озеленению территории ЛИУ. Так, при поддержке Правительства Новосибирской области, Департамента лесного хозяйства Новосибирской области и Колыванского лесхоза Новосибирской области благоустроена территория лечебно-исправительного учреждения в рамках Всероссийской акции «Живи, Лес!». В посадке саженцев елей, сосен, пихты и декоративных кустарников в ЛИУ-10 приняли участие не только члены ОНК, но и сотрудники ГУФСИН России по Новосибирской области, руководство ЛИУ и осужденные, проходящие лечение в учреждении. Важно подчеркнуть, что любая инициатива ОНК по Новосибирской области направленная на улучшение деятельности исправительных колоний, содействия лицам осужденным к лишению свободы встречает поддержку и понимание со стороны руководства ГУФСИН России по Новосибирской области.

Общественная наблюдательная комиссия по Новосибирской области является центральной площадкой для обучения кандидатов и новых членов ОНК по Сибирскому федеральному округу. Проведение обучающего семинара для сотрудников правоохранительных органов и членов ОНК субъектов РФ в Новосибирске инициировано членом Совета при Президенте РФ по развитию гражданского общества и правам человека Мария Каннабих. Главная цель семинара - расширить знания и навыки сотрудников правоохранительных органов и членов ОНК в сфере применения международных стандартов и положений законодательства РФ при обращении с лицами, содержащимися под стражей. Не случайно площадкой для проведения семинара выбрали Новосибирск, потому что ОНК здесь проводит серьезную работу. Отношения между членами ОНК и сотрудниками уголовно-исполнительной системы, полиции выстроены достаточно конструктивно и это приносит определенную пользу, что, к сожалению, не везде бывает. Члены ОНК по Новосибирской области поделились опытом работы с ОНК Республики Алтай, Омской, Томской и Кемеровской областей.

Кроме того, ОНК по Новосибирской области занимает активную позицию в следующих проектах. ОНК с представителями комиссии по делам несовершеннолетних и защите их прав принимают активное участие в работе по оценке поведения осужденных по системе «социальных лифтов». При поддержке ОНК проводится организация встреч осужденных-женщин со своими детьми, находящимися в детских домах. Ежегодные встречи проводят с целью сохранения социальных связей в женской колонии. Мероприятия посвящены празднованию «Дня матери» и «Дня защиты детей». В эти дни в гости к осужденным приезжают их дети из детских домов и участвуют в праздничном концерте. Ежегодно оказывается помощь в организации Всероссийского конкурса среди осужденных «Калина красная» в исправительных колониях.

ОНК подготовлены не только решения в форме заключений, предложений и обращений по результатам осуществления контроля, но и оказано содействие сотрудничеству общественных объединений, социально ориентированных некоммерческих организаций, администраций мест принудительного содержания осуществляющих полномочия по обеспечению законных прав и свобод, а также условий содержания лиц, находящихся в местах принудительного содержания.

\section{Baikal Research Journal}

электронный научный журнал Байкальского государственного университета 
Практическая деятельность ОНК по Новосибирской области, как показало время, способна повлиять на ситуацию в весьма актуальной для нашего общества области соблюдения прав и законных интересов личности.

Проводимая работа ОНК во взаимодействии с Общественной палатой Новосибирской области, Уполномоченным по правам человека по Новосибирской области, Уполномоченным по правам ребенка, Главным управлением Минюста России по Новосибирской области, ГУФСИН России по Новосибирской области, Прокуратурой Новосибирской области, Главное управление Министерства внутренних дел России по Новосибирской области, Управление Федеральной миграционной службы России по Новосибирской области, органами государственной власти Новосибирской области и общественными организациями позволяет обеспечить соблюдение законности, прав и законных интересов лиц в местах принудительного содержания.

C момента создания и начала работы ОНК прошло восемь лет и за этот сравнительно непродолжительный период времени их деятельность привлекает к себе повышенное внимание органов исполнительной власти и всех институтов гражданского общества.

Несмотря на положительные результаты работы Общественной наблюдательной комиссии в целях повышения әффективности применения института общественного контроля, ФЗ № 76-ФЗ требует своего системного анализа и дальнейшего совершенствования.

Анализ содержания ст. 15 ФЗ № 76-ФЗ позволяет сделать вывод о том, что ОНК вправе осуществлять общественный контроль: непосредственно в процессе своей деятельности; во взаимодействии с другими государственными и общественными органами; в составе общественных советов при ФСИН; в составе комиссий исполнительных учреждений (ИУ) при решении вопросов о перевод в составе комиссий ИУ при решении вопросов о переводе осужденных из одних условий отбывания наказания в др. Таким образом, в ст. 15 ФЗ № 76-ФЗ определены основные формы деятельности ОНК, среди которых посещение мест принудительного содержания для осуществления общественного контроля является первоначальным этапом всей деятельности ОНК. Безусловно, осуществление функций общественного контроля практически невозможна реализация основных форм деятельности комиссий.

В процессе осуществления контроля возникает ряд вопросов, которые законом не урегулированы. Например, следует остановиться на правовых проблемах проверки членами ОНК документации исправительных учреждений. Так, в ч. 5 ст. 16 ФЗ № 76-ФЗ указано, что члены ОНК в установленном законодательством РФ порядке могут запрашивать у администраций мест принудительного содержания и получать от них сведения и документы, необходимые для проведения общественного контроля и подготовки заключений, предложений или обращений ОНК. Однако в действующем законодательстве РФ четко не установлены правила направления соответствующих запросов администрации ИУ, а именно: форма запроса (устная или письменная); срок его выполнения; достаточно ли в случае направления письменного запроса администрации ИУ подписи одного или двух членов либо председателя ОНК. В практике ОНК по Новосибирской области письменные запросы для подготовки заключений оформляет только председатель ОНК.

Необходимо обратить внимание и на то, что в ФЗ № 76-ФЗ не конкретизировано, какие именно документы разрешается запрашивать для проведения общественного контроля. В соответствии с ст. 16.1 ФЗ № 76-ФЗ осуществление общественного контроля за обеспечением права лиц, находящихся в местах принудительного содержания, на охрану здоровья члены ОНК вправе с согласия этого лица или его законного представителя знакомиться с медицинской документацией, отражающей состояние его здоровья, беседовать по вопросам оказания меди-

\section{Baikal Research Journal}

электронный научный журнал Байкальского государственного университета 
цинской помощи с лицами, находящимися в местах принудительного содержания, медицинских учреждениях. В настоящее время медицинские подразделения выведены из подчинения начальников следственных изоляторов (СИЗО) и ИУ, что практике осложняет затребование информации у администрации ИУ о состоянии здоровья осужденного, получении им лечения в период отбывания наказания для составления заключения на жалобу или обращение.

В ст. 16.1 ФЗ № 76-ФЗ также нет ясности, что является медицинской документацией. Например, для подготовки заключения членами ОНК необходимо ознакомиться с журналом амбулаторного приема больных, медицинской картой больного, выпиской из стационара или другими документами. Кроме того, в статье не указана форма согласия осужденного на ознакомление членами ОНК с медицинской документацией, что является важным, т.к. разрешая ознакомиться с медицинской документацией в устной форме осужденный может отказаться от своего согласия в любое время.

Безусловно, изложенные выше недостатки правового регулирования снижают эффективность осуществления общественного контроля.

ФЗ № 76-ФЗ в соответствии со ст. 15 предусматривает, что одной из основных форм деятельности ОНК является участие в работе комиссии ИУ при решении вопросов о переводе осужденных из одних условий отбывания наказания в другие. Практика работы ОНК в комиссиях исправительных учреждений показывает, что мнение членов ОНК при решение вопросов связанных с переводом осужденного из одних условий отбывания наказания в другие может не учитываться, достаточно лишь присутствия в комиссии ИУ для решения этого вопроса. В связи с этим ст. 15 закона необходимо дополнить, что члены ОНК при решении вопросов о переводе осужденных из одних условий отбывания наказания в другие дают обязательное согласие администрации ИУ на перевод осужденных из одних условий в другие.

Проведенный анализ ФЗ № 76-ФЗ показал, что в целях эффективности работы ОНК необходимо разграничить и четко регламентировать не только контрольные полномочия ОНК, но и формы содействия лицам, содержащимся в местах изоляции от общества. Кроме того, в целях обеспечения эффективного общественного контроля необходимо минимизировать личностное усмотрение должностных лиц УИС и в связи с этим в ст. 23 УИК РФ предусмотреть, что члены ОНК имеют право участвовать в заседаниях комиссии исправительных учреждений при решении различных вопросов с правом обязательного согласия.

В п. 2 ст. 23 УИК РФ указано всего три учреждения, исполняющие уголовные наказания, подконтрольные ОНК - исправительные центры, исправительные учреждения и дисциплинарные воинские части. Таким образом, положения ст. 23 УИК РФ противоречат ст. 2 ФЗ № 76-ФЗ, где отсутствует упоминание об осужденных к принудительным работам, которые должны отбывать наказания в исправительных центрах. Возможно, это связано с тем, что наказание в виде принудительных работ вводится в действие только с 1 января 2017 г. Полагаем, что в ст. 23 УИК РФ необходимо указать учреждения, исполняющие уголовные наказания, подлежащие общественному контролю.

Существенным недостатком в процессе осуществления общественного контроля является то, что ОНК полностью находится на самофинансировании. Тот факт, что ОНК не является юридическим лицом, существенно сужает возможность получения финансирования из иных источников. Кроме этого, общественные объединения не всегда имеют возможность обеспечить свою деятельность, не говоря уже о финансировании лиц, которые будут осуществлять функции членов ОНК. В связи с этим необходимо внести дополнение в ст. 9 ФЗ № 76-ФЗ об обязательное финансирование деятельности ОНК органами власти субъекта Российской Фе-

\section{Baikal Research Journal}

электронный научный журнал Байкальского государственного университета 
дерации. Зарубежный опыт осуществления общественного контроля показывает, что в Великобритании организации финансируются за счет добровольных взносов частных и государственных компаний, а также пожертвований частных лиц. В Швейцарии действует специальный общественно-государственный контрольный орган - Национальная комиссия по предупреждению пыток. Работа комиссии полностью финансируется за счет федерального бюджета. Члены комиссии имеют право на возмещение расходов, связанных с осуществлением общественного контроля. Комиссия может нанимать экспертов и переводчиков, если это необходимо для проведения контрольных мероприятий [12, с. 93].

Можно констатировать, что в Российской Федерации создана система общественного контроля в исправительных учреждениях уголовно-исполнительной системы, а также в других местах принудительного содержания. Однако, эффективность деятельности по контролю за соблюдением прав и свобод личности в Российской Федерации, еще не удовлетворительна. Несмотря на эффективность деятельности наблюдателей, внутри их аппарата зачастую возникают противоречия, которые мешают продуктивной работе. Так, сложилась ситуация, когда председатели некоторых общественных наблюдательных комиссий запрещают членам комиссии посещать места принудительного содержания или отказывают в направлении уведомлений о посещении. Члены Совета при Президенте РФ по правам человека и развитию гражданского общества считают такую ситуацию недопустимой и противоречащей закону, ведь наряду с общественными наблюдательными комиссиями самостоятельными субъектами общественного контроля являются и их члены. С целью предотвращения злоупотреблений полномочиями со стороны председателей общественных наблюдательных комиссий необходимо законодательно установить их обязанность направления уведомлений о посещении мест принудительного содержания членами комиссий [11, с. 1397]. В некоторых субъектах РФ общественных наблюдателей не пускают в места принудительного содержания и лишь в отдельных регионах власти считают, что члены общественных наблюдательных комиссий приносят реальную пользу, снижают социальную напряженность внутри исправительных колоний, следственных изоляторов, что способствует менее болезненному возврату бывших осужденных к нормальной жизни в обществе.

Авторы некоторых публикаций находят положительные тенденции, связанные с введением общественного контроля и отмечают, что в целом законодательное регулирование общественного контроля в России с учетом того, что данный опыт в той форме, в которой это установлено Федеральным законом, для нашей страны новый - можно оценить позитивно, но учитывая практику реализации деятельность ОНК нуждается в дальнейшем совершенствовании.

Законодательное урегулирование указанных выше вопросов позволит эффективнее осуществлять общественный контроль, так как ОНК заинтересованы в повышении качества работы учреждений и органов, исполняющих наказания, до уровня европейских стандартов обращения с осужденными, сокращении рецидива преступлений, совершенных лицами, отбывающими наказания в виде лишения свободы.

На основании анализа практики осуществления общественного контроля, важно отметить, что участие в этом процессе не всегда пользуется уважением. Кроме этого, в некоторых субъектах РФ члены ОНК несут расходы по осуществлению общественного контролю. В связи с этим не только популярность участия в ОНК в регионах низкая, но и существуют трудности в формировании состава комиссии.

В настоящее время отечественное законодательство оставляет некоторые вопросы взаимоотношений институтов гражданского общества и государственных органов на их субъективное усмотрение, что будет затруднять развитие и реализацию

\section{Baikal Research Journal}

электронный научный журнал Байкальского государственного университета 
института общественного контроля. Эффективный общественный контроль за деятельностью УИС может быть осуществлен только при условии глубокого понимания сути работы УИС, что невозможно без подготовки членов ОНК к такому сложному и ответственному процессу; финансирования и создания надлежащей информационной, материально-технической базы ОНК; устранения правовых пробелов и внесения изменений в действующее уголовно-исполнительное законодательство и Ф3 «Об общественном контроле за обеспечением прав человека в местах принудительного содержания и содействия лицам, находящимся в местах принудительного содержания»; конструктивного подхода во взаимоотношениях и взаимодействии с государственными органами и другими институтами гражданского общества.

Отсутствие четкой правовой регламентации общественного контроля в известном смысле можно считать пробелом, допущенным законодателем, игнорированием требований международно-правовых актов, закрепляющих права и свободы человека и гражданина [4, с. 34], и прежде всего Всеобщей декларации прав человека 1948 г. ${ }^{4}$, Международного пакта об экономических, социальных и культурных правах человека 1966 г. ${ }^{5}$, и др.

На практике преобладающей формой деятельности ОНК стал именно общественный контроль за обеспечением прав человека в местах принудительного содержания, а не содействие лицам, находящимся в местах принудительного содержания. Полагаем, что вторая форма деятельности ОНК, особенно с учетом наличия многих организационных и иных проблем, «копившихся» десятилетиями в УИС, должна реализовываться членами ОНК наравне с первой.

Более активное привлечение представителей общественности к исполнению уголовных наказаний, позволит повысить эффективность исправительного процесса, а также реализации их прав и законных интересов. Это также повысит эффективность общественного контроля за деятельностью учреждений и органов, исполняющих наказания, а также обеспечит в большей степени прозрачность деятельности уголовно-исполнительной системы.

Бесспорно, что наличие общественного контроля является важным гарантом соблюдения законности в деятельности УИС, средством оптимальной защиты нарушенных прав и законных интересов осужденных, а также безусловным показателем демократичности нашего государства. Данное исследование позволяет выявить недостатки и сформулировать направления обеспечения законности в области исполнения наказаний, в том числе путем осуществления общественного контроля. Рассмотрение проблем и положительной практики будет способствовать повышению эффективности деятельности ОНК.

\section{Список использованной литературы}

1. Молокова М. А. Гражданское общество как фактор политической модернизации : дис. ... д-ра полит. наук : 23.00.02 / М. А. Молокова. - Курск, 2011. - 384 с.

2. Федоров В. В. Общественный контроль за деятельностью уголовно-исполнительной системы как форма взаимодействия гражданского общества с государством : дис. ... канд. юрид. наук : 12.00.01 / В. В. Федоров. - Владимир, 2006. - 171 с.

3. Железная Ю. Ю. Историко-правовые основы становления общественного контроля пенитенциарных учреждений в дореволюционной России / Ю. Ю. Железная // Юридическая наука: история и современность. - 2015. - № 8. - С. 57-67.

4. Андреева Л. А. К вопросу об общественном контроле / Л. А. Андреева // Вопросы современной юриспруденции : сб. ст. по материалам XLIII Междунар. науч.-практ. конф. / отв. ред. А. И. Гулин. - Новосибирск : СибАК, 2014. - № 11 (42). - С. 33-38.

${ }^{4}$ Всеобщая декларация прав человека 1948 г. (принята Генер. Ассамблеей ООН 10 дек. 1948 г.) // Российская газета. 1998. 10 дек.

${ }^{5}$ Международный пакт об экономических, социальных и культурных правах (принят Генер. Ассамблеей ООН 16 дек. 1966 г.) [Электронный ресурс] // СПС «КонсультантПлюс».

\section{Baikal Research Journal}

электронный научный журнал Байкальского государственного университета 
5. Реент Я. Ю. Организация и правовое регулирование общественного контроля за обеспечением прав, свобод и законных интересов лиц, содержащихся в учреждениях уголовно-исполнительной системы : дис. ... канд. юрид. наук : 12.00.11 / Я. Ю. Реент. — Рязань, 2014. $-226 \mathrm{c}$.

6. Бычкова Т. С. Взаимодействие государства и гражданского общества в механизме реализации юридической ответственности : дис. ... канд. юрид. наук : 12.00.01 / Т. С. Бычкова. - Владимир, 2008. - 190 с.

7. Гражданское общество в России: структуры и сознание / отв. ред. К. Г. Холодковский. - М. : Наука, 1998. - 254 с.

8. Зеленев В. А. Становление гражданского общества в России: оптимизация взаимодействия подсистем общества : дис. ... канд. социол. наук : 22.00.01 / В. А. Зеленев. Саратов, 2004. - 153 с.

9. Крусс В. И. Институциональные инновации в российской уголовно-исполнительной системе и их значение для механизма конституционного гарантирования прав и свобод человека и гражданина / В. И. Крусс, В. В. Копылов // Конституционное и муниципальное право. - 2009. - № 18. - С. 32-38.

10. Минстер М. В. Практика реализации комплексных мер по подготовке к освобождению женщин, осужденных к лишению свободы / М. В. Минстер // Криминологический журнал Байкальского государственного университета экономики и права. - 2011. № 2. - C. 47-53.

11. Савченко М. С. Правовое обеспечение общественного контроля: проблемы и перспективы развития / М. С. Савченко, А. С. Грибанова // Политематический сетевой электронный научный журнал Кубанского государственного аграрного университета. 2015. - № 110. - C. 1396-1408.

12. Спасенников Б. А. Механизм общественного контроля обеспечения прав, свобод и законных интересов осужденных в иностранных государствах / Б. А. Спасенников, Ю. Ю. Железная // Вестник Кузбасского института. - 2015. - № 4. - С. 88-96.

\section{References}

1. Molokova M. A. Grazhdanskoe obshchestvo kak faktor politicheskoi modernizatsii. Dokt. Diss. [Civil society as a factor of political modernization. Doct. Diss.]. Kursk, 2011. 384 p.

2. Fedorov V. V. Obshchestvennyi kontrol' za deyatel'nost'yu ugolovno-ispolnitel'noi sistemy kak forma vzaimodeistviya grazhdanskogo obshchestva s gosudarstvom. Kand. Diss. [Public control of correctional system activities as a form of interaction of civil society with state. Cand. Diss.]. Vladimir, 2006. 171 p.

3. Zheleznaya Yu. Yu. Historical and legal bases of formation of public control penitentiaries in pre-revolutionary Russia. Yuridicheskaya nauka: istoriya i sovremennost' = Juridical Science: History and Modern Times, 2015, no. 8, pp. 57-67. (In Russian).

4. Andreyeva L. A. On issue of public control. In Gulin A. I. (ed.). Voprosy sovremennoi yurisprudentsii. Materialy XLIII Mezhdunarodnoi nauchno-prakticheskoi konferentsii [Issues of modern jurisprudence. Materials of the $43^{\text {rd }}$ International Research Conference]. Novosibirsk, SibAK Publ., 2014, no. 11 (43), pp. 33-38. (In Russian).

5. Reent Ya. Yu. Organizatsiya $i$ pravovoe regulirovanie obshchestvennogo kontrolya za obespecheniem prav, svobod i zakonnykh interesov lits, soderzhashchikhsya $v$ uchrezhdeniyakh ugolovno-ispolnitel'noi sistemy. Kand. Diss. [Organization and legal regulation of public control of providing rights, freedoms and legal interests of person kept in correctional facilities. Cand. Diss.]. Ryazan, 2014. 226 p.

6. Bychkova T. S. Vzaimodeistvie gosudarstva i grazhdanskogo obshchestva $v$ mekhanizme realizatsii yuridicheskoi otvetstvennosti. Kand. Diss. [Interaction of state and civil society in mechanism of implementing juridical responsibility. Cand. Diss.]. Vladimir, 2008. $190 \mathrm{p}$.

7. Kholodkovskii K. G. (ed.). Grazhdanskoe obshchestvo $v$ Rossii: struktury i soznanie [Civil society in Russia: structures and conciseness. Moscow, Nauka Publ., 1998. 254 p.

8. Zelenev V. A. Stanovlenie grazhdanskogo obshchestva $v$ Rossii: optimizatsiya vzaimodeistviya podsistem obshchestva. Kand. Diss. [Establishing civil society in Russia: optimizing interactions of society's subsystems. Cand. Diss.]. Saratov, 2004. 153 p.

9. Kruss V. I., Kopylov V. V. Institutional innovations in Russian correctional system and their significance for mechanism of constitutional guarantee of human and citizen's rights and

\section{Baikal Research Journal}


freedom. Konstitutsionnoe i munitsipalnoe pravo $=$ Constitutional and Municipal Law, 2009, no. 18 , pp. 32-38. (In Russian).

10. Minster M. V. Practice of implementing complex measures in preparing discharge of women sentenced to imprisonment Criminology Journal of Baikal National University of Economics and Law, 2011, no. 2, pp. 47-53. (In Russian).

11. Savchenko M. S., Gribanova A. S. Legal support for public control: problems and prospects. Politematicheskii setevoi elektronnyi nauchnyi zhurnal Kubanskogo gosudarstvennogo agrarnogo universiteta $=$ Polythematic Online Scientific Journal of Kuban State Agrarian University, 2015, no. 110, pp. 1396-1408. (In Russian).

12. Spasennikov B. A., Zheleznaya Yu. Yu. Mechanism of public control in ensuring the rights, freedoms and legitimate interests of convicts in foreign countries. Vestnik Kuzbasskogo instituta $=$ Bulletin of the Kuzbass Institute, 2015, no. 4, pp. 88-96. (In Russian).

\section{Информация об авторе}

Минстер Марина Владиславовна - кандидат юридических наук, доцент, кафедра уголовного права, Новосибирский юридический институт (филиал) Национального исследовательского Томского государственного университета, 630007, г. Новосибирск, ул. Советская, 7; кафедра уголовного права и процесса, Новосибирский государственный технический университет, 630073, г. Новосибирск, просп. К. Маркса; 20, член Общественной наблюдательной комиссии по Новосибирской области; e-mail: mminster1@yandex.ru.

\section{Author}

Marina V. Minster - PhD in Law, Associate Professor, Chair of Criminal Law, Novosibirsk Juridical Institute (branch), National Research Tomsk State University, 7 Sovetskaya St., 630007, Novosibirsk, Russian Federation; Chair of Criminal Law and Process, Novosibirsk State Technical University, 20 K. Marx Av., 630073, Novosibirsk, Russian Federation; e-mail: mminster1@yandex.ru.

\section{Библиографическое описание статьи}

Минстер М. В. Общественный контроль за обеспечением прав лиц, содержащихся в местах лишения свободы: законодательство и практика реализации / М. В. Минстер // Baikal Research Journal. — 2016. - T. 7, № 6. - DOI: 10.17150/2411-6262.2016.7(6).18.

\section{Reference to article}

Minster M. V. Public control of providing rights of persons kept in places of detention: legislation and implementation practice. Baikal Research Journal, 2016, vol. 7, no. 6. DOI: 10.17150/2411-6262.2016.7(6).18. (In Russian).

\section{Baikal Research Journal}

